\title{
PERILAKU HIDUP BERSIH DAN SEHAT (PHBS) PADA SISWA MADRASAH IBTIDAIYAH AZ-ZAHIR PALEMBANG
}

\section{THE RELATIONSHIP BETWEEN CLEAN AND HEALTHY LIFE BEHAVIORS IN MADRASAH IBTIDAIYAH AZ- ZAHIR STUDENT PALEMBANG}

\author{
Oleh \\ Hamyatri Rawalilah¹,Santi Rosalina², Maria Ulpah³ \\ (Program Studi Kesehatan masyarakat, STIK Bina husada Palembang) \\ Email : hamyatri69@gmail.com
}

\begin{abstract}
Problems that occur in Madrasah Ibtidayah Az-zahir palembang is still low knowledge and attitude of students to healthy lifestyle so that not yet running optimally program CHLB school. The purpose of this research is knowledge and attitude toward basic sanitation with clean and healthy life behavior. The research was conducted on April , 2018. The method is used a quantitative descriptive method with cross sectional design. The population in this study are 5th and 6th grade of Madrasah Ibtidayah Az-Zahir Palembang in 2018. There are 98 respondents in this research This research in taken by using non randon sampling tecnique. The results of research by distributing questionnaires showed that students who always wash hand used soap $(38,8)$, the students were always eaten in the canteen $67,3 \%$ ), the students who did not take exercise every week $67,3 \%$, and students were always throwing trash in its place $70,4 \%$.But in the class and bathroom food sold in the canteen school was not closed and still there were students who follow gymnastics every week, and still there was garbage strewn in the school. Thus it can be concluded that the students have learned about (CHLB) in the school, but unavailability of supporting facilities and infrastructure. . It is recommended for schools and health workers to further improve counseling about (CHLB).
\end{abstract}

Keywords : Behavior, clean and healthy life

\begin{abstract}
ABSTRAK.
Masih rendahnya pengetahuan dan sikap siswa terhadap pola hidup sehat sehingga belum berjalannya secara optimal program PHBS sekolah. Perilaku hidup bersih dan sehat adalah segala perilaku kesehatan yang dilakukan atas kesadaran. Tujuan penelitian ini diketahuinya perilaku hidup bersih dan sehat pada siswa Madrasah Ibtidayah Az-Zahir Palembang. Penelitian dilakukan pada bulan April 2018. Metode yang digunakan adalah metode deskriptif kuantitatif dengan rancangan cross sectional. Populasi penelitian ini adalah siswa kelas 5 dan 6 Madrasah Ibtidayah AZ-Zahir Palembang tahun 2018. Sampel berjumlah 98 responden dan diambil menggunakan teknik non random sampling. Hasil penelitian responden Perilaku siswa selalu cuci tangan pakai sabun sebelum makan sebesar $38,8 \%$. Perilaku siswa selalu mengkonsumsi jajanan di kantin sekolah sebanyak $67,3 \%$. Perilaku siswa selalu mengikuti senam setiap satu minggu sekali sebesar $67,3 \%$. Perilaku siswa selalu membuang sampah pada tempatnya sebesar $70,4 \%$. Namun berdasarkan hasil observasi tidak tersedia tempat cuci tangan dan sabun baik di area kelas maupun di area kamar mandi, makanan yang dijual dikantin sekolah tidak ditutup, dan masih ada sampah yang berserakan disekolah. Dengan demikian dapat disimpulkan bahwa siswa telah mengetahui tentang PHBS disekolah namun, belum tersedianya sarana dan prasarana pendukung PHBS.Disarankan untuk pihak sekolah dan petugas kesehatan untuk lebih meningkatkan lagi penyuluhanpenyuluhan tentang PHBS .
\end{abstract}

Kata Kunci : Perilaku, hidup bersih dan sehat 


\section{PENDAHULUAN}

Masalah kesehatan merupakan suatu masalah yang sangat kompleks, yang saling berkaitan dengan masalah-masalah lain diluar kesehatan itu sendiri. Demikian pula pemecahan masalah kesehatan masyarakat, tidak hanya dilihat dari segi kesehatannya sendiri tetapi harus dilihat dari seluruh segi yang ada pengaruhya terhadap masalah"sehatsakit" atau kesehatan tersebut, (Rahmawati, 2014)

Derajat kesehatan masyarakat dipengaruhi oleh empat faktor utama, yakni: linkungan, perilaku, pelayanan kesehatan, dan keturunan (herediter). Karena itu upaya untuk memelihara dan meningkatkan derajat kesehatan masyarakat harus ditunjukan pada keempat faktor utama tersebut secara bersama-sama,( Kepmenkes RI,2008).

Pendidikan atau promosi kesehatan pada hakikatnya adalah upaya intervensi yang ditunjukan pada faktor perilaku. Namun pada kenyataannya tiga faktor yang lain perlu intervensi pendidikan atau promosi kesehatan juga, karena perilaku juga berperan pada faktor-faktor tersebut. Apabila lingkungan baik dan sikap masyarakat positif maka lingkungan dan fasilitas tersebut niscaya akan dimanfaatkan atau digunakan oleh masyarakat, (Kepmenkes, 2008).

Berdasarkan data Susenas (survey sosial ekonomi nasional) tahun 2007 menyebutkan bahwa sekitar 3\% anak-anak mulai merokok sejak kurang dari usia 10 tahun. Persentase orang merokok tertinggi $(64 \%)$ berada pada kelompok usia remaja (10-19 tahun). Dan sebagian besar (82\%),penduduk yang berusia 10 tahun ke atas kurang melakukan aktivitas fisik, dengan kategori (73\%) kurang bergerak dan $(9 \%)$ tidak terbiasa melakukan aktifitas fisik. Belum lagi persoalan keamanan makanan yang dijual di sekitar sekolah yang belum menerapkan prinsipprinsip Hygiene. Bila perilaku hidup bersih dan sehat (PHBS) ini tidak dilakukan dengan baik maka akan menimbulkan dampak yang tidak diinginkan yaitu munculnya berbagai penyakit. Hal ini dapat dilihat melalui hasil survey Subdit diare tahun 2 $\mathrm{C0} 2$ dan 2003 pada 40 SD di 10 propinsi menunjukkan prevalensi kecacingan berkisar antara 2,2 \% - 6,3\% . Berdasarkan hasil pengamatan tahun 2008, ditemukan kasus diare sebanyak 12.253 (38,11\%). Oleh karena itu, penanaman nilai-nilai PHBS di sekolah merupakan kebutuhan mutlak dan dapat dilakukan melalui pendekatan UKS,( Maryuni, 2013).

Perilaku Hidup Bersih dan Sehat (PHBS) merupakan salah satu program prioritas pemerintah melalui puskesmas dan menjadi sasaran luaran dalam penyelenggaraan pembangunan kesehatan, seperti yang disebutkan pada rencana strategis (Renstra) Kementrian Kesehatan tahun 2010-2014, (Kemenkes, 2011). Sasaran PHBS tidak hanya terbatas tentang Hygiene, namun harus lebih komprehensif dan luas, mencakup perubahan lingkungan fisik, lingkungan biologi dan lingkungan sosial-budaya masyarakat sehingga tercipta lingkungan yang berwawasan kesehatan dan perubahan perilaku hidup bersih dan sehat. Lingkungan fisik seperti sanitasi dan hygiene perorangan, keluarga dan masyarakat, tersedianya air bersih, lingkungan perumahan, fasilitas mandi, cuci dan kakus (MCK), dan pembuangan sampah serta limbah. Lingkungan biologi adalah Flora dan Fauna. Lingkungan sosial-budaya seperti pengetahuan, sikap perilaku dan budaya setempat yang berhubungan dengan PHBS, (Maryuni, 2013).

Sekolah sebagai salah satu sasaran PHBS di tatanan institusi pendidikan. Hal ini disebabkan karena banyaknya data yang menyebutkan bahwa munculnya sebagian penyakit yang sering menyerang anak usia sekolah (usia 6-10), misalnya diare, kecacingan, dan anemia ternyata umumnya berkaitan dengan PHBS. Dampak lainnya dari kurang dilaksanakan PHBS diantaranya yaitu suasana belajar yang tidak mendukung karena lingkungan sekolah yang kotor, menurunnya semangat dan prestasi belajar dan mengajar disekolah, menurunkan citra sekolah di masyarakat umum. Oleh karena itu, penanaman nilainilai PHBS disekolah merupakan kebutuhan mutlak dan dapat dilakukan melalui pendekatan usaha kesehatan sekolah (Rahmawati, 2014).

Berdasarkan latarbelakang diatas, maka peneliti ingin meneliti tetang perilaku hidup bersih dan sehat di madrasah ibtidayah Az-zahir Palembang.

\section{METODE}

Penelitian ini menggunakan metode penelitian deskriptif kuantitatif. Penelitian deskriptif kuantitatif merupakan usaha sadar dan sistematis untuk memberikan jawaban teradap suatu masalah dan atau mendapatkan informasi lebih mendalam dan luasa 
terhadap suatu fenomena dengan menggunakan tahap-tahap penelitian dengan pendekatan kuantitatif. Penelitian ini dilaksanakan di sekolah Madrasah Ibtidaiyah Az-Zahir Palembang yang bertempat di Kelurahan 8 Ulu Kecamatan Jakabaring Palembang. Besar sampel dalam penelitian ini sebanyak 98 siswa

HASIL

Analisa ini digunakan untuk memperoleh gambaran distribusi frekuensi dan persentase dari variabel dependen yaitu perilaku hidup bersih dan sehat dan variabel independen meliputi cuci tangan pakai sabun, membuang sampah pada tempatnya, Jajanan sehat, dan aktifitas fisik olah raga. Hasil penelitian analisis univariat dalam betuk tabel dan teks.

\section{Cuci Tangan Pakai Sabun}

\section{Tabel 1}

Distribusi Frekuensi Cuci Tangan Pakai Sabun (CPTS) Pada Siswa Madrasah Ibtidaiyah Az-Zahir Palembang

\begin{tabular}{|c|c|c|c|c|c|c|c|c|c|}
\hline \multirow{2}{*}{ No } & \multirow{2}{*}{ CPTS } & \multicolumn{2}{|c|}{ Selalu } & \multicolumn{2}{|c|}{ Sering } & \multicolumn{2}{|c|}{ Kadang } & \multicolumn{2}{|c|}{$\begin{array}{c}\text { Tidak } \\
\text { Pernah }\end{array}$} \\
\hline & & Frek & $\%$ & Frek & $\%$ & Frek & $\%$ & Frek & $\%$ \\
\hline 1. & $\begin{array}{l}\text { CPTS } \\
\text { sebelum } \\
\text { dan } \\
\text { sesudah } \\
\text { makan }\end{array}$ & 38 & 38,8 & 28 & 28,6 & 17 & 17,3 & 15 & 15,3 \\
\hline 2. & $\begin{array}{l}\text { CPTS } \\
\text { setelah } \\
\text { bermain }\end{array}$ & 35 & 35,7 & 21 & 21,4 & 28 & 28,6 & 14 & 14,2 \\
\hline 3. & $\begin{array}{l}\text { CPTS } \\
\text { dengan } \\
\text { air yang } \\
\text { mengalir } \\
\text { setelah } \\
\text { BAB } \\
\text { dan } \\
\text { BAK }\end{array}$ & 25 & 25,5 & 27 & 27,6 & 28 & 28,5 & 18 & 18,4 \\
\hline 4. & $\begin{array}{l}\text { CPTS } \\
\text { setelah } \\
\text { member } \\
\text { sihkan } \\
\text { lingkung } \\
\text { an kelas }\end{array}$ & 31 & $\beta 1,6$ & 25 & 25,5 & 23 & 23,5 & 19 & 19,4 \\
\hline
\end{tabular}

Dilihat dari tabel 1 distribusi Frekuensi cuci tangan menggunakan sabun sebelum dan sesudah makan sebesar $38,8 \%$, cuci tangan menggunakan sabun setelah bermain 35,7\%, cuci tangan menggunakan sabun dengan air yang mengalir setelah BAB dan BAK 25,5\%, dan cuci tangan menggunakan sabun setelah membersihkan lingkungan kelas 31 ,

\section{.Mengkonsumsi Jajanan Sehat}

Tabel 2

Distribusi Frekuensi

Konsumsi Jajanan Sehat Pada Siswa Madrasah Ibtidayah Az-Zahir Palembang

\begin{tabular}{|c|l|c|c|c|c|c|c|c|c|}
\hline \multirow{2}{*}{ No } & \multicolumn{2}{|l|}{$\begin{array}{l}\text { Konsumsi } \\
\text { Jajanan sehat }\end{array}$} & \multicolumn{2}{|c|}{ Selalu } & \multicolumn{2}{|c|}{ Sering } & \multicolumn{2}{c|}{ Kadang } & \multicolumn{2}{c|}{$\begin{array}{l}\text { Tidak } \\
\text { Pernah }\end{array}$} \\
\cline { 2 - 10 } & Frek & $\%$ & Frek & $\%$ & Frek & $\%$ & Frek & $\%$ \\
\hline 1. & $\begin{array}{l}\text { Jajan dikantin } \\
\text { sekolah }\end{array}$ & 66 & 67,3 & 27 & 27,5 & 4 & 4,08 & 1 & 1,03 \\
\hline 2. & $\begin{array}{l}\text { Membeli } \\
\text { jajanan di luar } \\
\text { pagar sekolah }\end{array}$ & 10 & 10,2 & 29 & 29,6 & 51 & 52,0 & 8 & 8,2 \\
\hline 3. & $\begin{array}{l}\text { Mengalami } \\
\text { sakit perut } \\
\text { setelah } \\
\text { memakan } \\
\text { jajanan di } \\
\text { kantin sekolah }\end{array}$ & 2 & 2,1 & 4 & 4,1 & 7 & 7,1 & 85 & 86,7 \\
\hline 4. & $\begin{array}{l}\text { Membawa } \\
\text { bekal dari } \\
\text { rumah saat } \\
\text { sekolah }\end{array}$ & 5 & 5,1 & 11 & 11,2 & 33 & 33,7 & 49 & 50 \\
\hline
\end{tabular}

Dilihat dari tabel 2 distribusi frekuensi mengkonsumsi jajanan dikantin sekolah sebesar $67,3 \%$, kadang-kadang membeli jajanan diluar pagar sekolah $52,0 \%$, tidak pernah mengalami sakit perut setelah memakan jajanan dikantin sekolah $86,7 \%$, dan tidak pernah membawa bekal dari rumah sebesar $50 \%$.

\section{Olah Raga dan Aktifitas Fisik Yang Teratur}

Tabel 3 Distribusi Frekuensi Olah Raga dan Aktifitas Fisik yang teratur Pada Siswa Madrasah Ibtidayah Palembang

\begin{tabular}{|c|l|c|c|c|c|c|c|c|c|}
\hline & \multirow{2}{*}{$\begin{array}{c}\text { Olah raga dan } \\
\text { aktifitas fisik yang } \\
\text { teratur }\end{array}$} & \multicolumn{2}{|c|}{ Selalu } & \multicolumn{2}{|c|}{ Sering } & \multicolumn{2}{|c|}{ Kadang } & \multicolumn{2}{|c|}{$\begin{array}{c}\text { Tidak } \\
\text { pernah }\end{array}$} \\
\cline { 3 - 10 } & Frek & $\%$ & Frek & $\%$ & Frek & $\%$ & Frek & $\%$ \\
\hline 1. & $\begin{array}{l}\text { Mengikuti senam } \\
\text { setiap satu minggu } \\
\text { sekali }\end{array}$ & 66 & 67,3 & 16 & 16,4 & 11 & 11,2 & 5 & 5,1 \\
\hline 2. & $\begin{array}{l}\text { Mengikuti pelajaran } \\
\text { olah raga dengan } \\
\text { sungguh-sungguh }\end{array}$ & 80 & 81,6 & 15 & 15,4 & 2 & 2,0 & 1 & 1,0 \\
\hline 3. & $\begin{array}{l}\text { Melakukan olah raga } \\
\text { pagi sebelum } \\
\text { kesekolah }\end{array}$ & 6 & 6,1 & 9 & 9,2 & 11 & 11,2 & 72 & 73,5 \\
\hline
\end{tabular}




\begin{tabular}{|c|l|l|l|l|l|l|l|l|l|}
\hline 4. & $\begin{array}{l}\text { Mengalami kantuk } \\
\text { setelah berolah raga }\end{array}$ & 3 & 3,1 & 2 & 2,0 & 2 & 2,0 & 91 & 92,9 \\
\hline
\end{tabular}

Dilihat dari tabel 3 distribusi frekuensi siswa yang selalu mengikuti senam setiap satu minggu sekali sebesar $67,3 \%$, mengikuti pelajaran olah raga dengan sungguh-sugguh $81,6 \%$, tidak pernah melakukan olah raga pagi sebelum kesekolah $73,5 \%$, dan tidak pernah mengalami kantuk setelah berolah raga $92,9 \%$.

\section{Membuang Sampah Pada Tempatnya}

Tabel 4

Distribusi Frekuensi Membuang Sampah Pada

Tempatnya Pada Siswa Madrasah Ibtidayah Az-Zahir Palembang

\begin{tabular}{|c|c|c|c|c|c|c|c|c|c|}
\hline \multirow[t]{2}{*}{ No. } & \multirow{2}{*}{$\begin{array}{l}\text { Membuang } \\
\text { sampah pada } \\
\text { tempatnya }\end{array}$} & \multicolumn{2}{|c|}{ Selalu } & \multicolumn{2}{|c|}{ Sering } & \multicolumn{2}{|c|}{ Kadang } & \multicolumn{2}{|c|}{$\begin{array}{l}\text { Tidak } \\
\text { Pernah }\end{array}$} \\
\hline & & Frek & & Frek & $\%$ & Frek & $\%$ & Frek & $\%$ \\
\hline 1. & $\begin{array}{l}\text { Membuang } \\
\text { sampah pada } \\
\text { kotak sampah } \\
\text { yang telah } \\
\text { disiapkan sekolah }\end{array}$ & 69 & 70,4 & 19 & 19,4 & 5 & 5,1 & 5 & 5,1 \\
\hline 2. & $\begin{array}{l}\text { Membuang } \\
\text { sampah } \\
\text { sembarangan }\end{array}$ & 20 & 20,4 & 11 & 11,2 & 14 & 14,3 & 53 & 54,1 \\
\hline 3. & $\begin{array}{l}\text { Melakukan } \\
\text { pembakaran } \\
\text { sampah disekolah }\end{array}$ & 3 & $3,1 \mid$ & 5 & 5,1 & 17 & 17,3 & 73 & 74,5 \\
\hline
\end{tabular}

Dilihat dari tabel 4 Distribusi frekuensi membuang sampah pada kotak sampah yang telah disiapkan sekolah sebesar 70,4\%, tidak pernah membuang sampah sembarangan $54,1 \%$, dan tidak pernah melakukan pembakaran sampah sebesar $74,5 \%$.

\section{PEMBAHASAN}

\section{Perilaku Cuci Tangan Menggunakan Sabun}

Berdasarkan hasil penelitian Madrasah Ibtidayah Az-Zahir Palembang tentang Perilaku Hidup Bersih dan Sehat (PHBS) dengan indikator cuci tangan pakai sabun dengan air yang mengalir menunjukan bahwa siswa yang menjawab selalu mencuci tangan mengunakan sabun sebelum dan sesudah makan sebanyak $38,8 \%$, selalu cuci tangan pakai sabun setelah bermain sebanyak $35,7 \%$, selalu cuci tangan menngunakan sabun dan air yang mengalir setelah BAB dan BAK sebanyak $25,5 \%$, dan siswa yang selalu cuci tangan setelah membersihkan lingkungan kelas seban 31,6\%. Hasil analisis univariat tersebut sejalan dengan hasil observasi yang dilakukan oleh peneliti, bahwa dilokasi penelitian tidak tersedia tempat cuci tangan dan sabun untuk mencuci tangan di dalam kamar mandi sekolah.

Hal ini menunjukan bahwa siswa mengetahui pentingnya cuci tangan pakai sabun namun belum dapat dilaksanakan dengan maksimal karena tidak ditunjang oleh ketersediaan sarana di sekolah padahal perilaku siswa mencuci tangan pakai sabun dengan benar akan dapat menurunkan angka kejadian diare . Oleh karena itu kebiasaan Cuci tanganpakai sabun sebaiknya dibiasakan sejak usia sekolah. Data Riset Kesehatan Dasar RI sebelumnya tahun 2009 menyebutkan bahwa setiap tahun100.000 anak Indonesia meninggal akibat diare.

Sejalan dengan penelitian Djarkoni (2014) yang dilakukan di SD Advent Sario kota Manado, didapatkan hasil bahwa anak sekolah dasar yang memiliki perilakubaik dalam mencuci tangan pakai sabun sebanyak $90,3 \%$ dan $9,7 \%$ anaksekolah dasar yang kurang memiliki perilaku baik dalammencuci tangan. Perilaku cuci tangan pakai sabun merupakan tindakan kesehatan yang paling murahdan efektif yang dapat diprogramkan untuk mengurangi resiko penularan berbagai penyakit yang ditularkan melalui air , makanan dan kurangnya perilaku hidup bersih dan sehat, salah satu contohnya diare.

Mencuci tangan dengan sabun dikenal juga sebagai salah satu upaya untuk pencegahan berbagai penyakit. Hal ini disebabkan oleh karena pengetahuan tentang cuci tangan pakai sabun yang baik untukkesehatan dapat membantu kita untuk mengetahui cara yang efektif untuk mencegah penyebaran kuman, bakteri dan virus. Mencuci tangan dengan baik dan benar sebaiknya harus menggunakan sabun, Cuci tangan dengan air saja tidak cukup melindungi seseorang dari kuman penyakit yang menempel ditangan. Zat-zat yang ada dalam sabun seperti TCC dantriclosan lebih efektif dalam membunuh kuman dibandingkan hanya mengandalkan aliran air dan gesekan saat mencuci tangan dalam membasmi kuman.

\section{Mengkonsumsi Jajanan Sehat}

Hasil analisis univariate terhadap perilaku hidup bersih dan sehat (PHBS) pada siswa Madrasah Ibtidayah Az-Zahir Palembang dengan indikator 
konsumsi jajanan sehat menujukan bahwa siswa yang selalu jajan dikantin sekolah sebanyak $67,3 \%$. Hasil observasi menunjukan tersedianya kantin di dalam sekolah sehingga kebersihan dan kesehatan jajanan yang dijual dapat dengan mudah diawasi oleh pihak sekolah.

Sementara itu masih ada siswa yang kadang membeli jajanan diluar pagar sekolah sebanyak $52,0 \%$. Berdasarkan hasil tersebut, dapat dikatakan bahwa tersedianya katin didalam sekolah tidak mempengaruhi keinginan siswa untuk membeli jajajan diluar pagar. Hal ini dapat terjadi karena kurangnya pengawasan dari pihak sekolah dan makanan yang dijual diluar sekolah banyak terpajan oleh debu dan lalat serta kualitas makanan yang dijual tidak bisa diamati secara langsung oleh guru. Selain itu tidak adanya larangan dari guru kepada siswa untuk jajan diluar pagar sekolah.

Berkaitan dengan hal tersebut, siswa mengaku tidak pernah mengalami sakit perut setelah memakan jajanan dikantin sekolah sebanyak $86,7 \%$,. Tetapi terdapat siswa yang selalu mengalami sakit perut setelah memakan jajanan di kantin sekolah sebanyak 2,4\%, sering mengalami sakit perut sebanyak $4,1 \%$, dan siswa yang kadang-kadang mengalami sakit perut setelah memakan jajanan dikantin sekolah sebanyak $7 \%$. Hal ini terjadi karena berdasarkan hasil observasi, makanan yang dijual dikantin sekolah tidak ditutup dengan plastik ataupun penutup makanan sehingga makanan tersebut dihinggapi debu dan lalat. Kurangnya kesadaran dari penjual untuk menutup makanan yang dijual dan kurangnya pengawasan serta tidak adanya teguran dari guru terhadap penjual sehingga masih ada siswa yang mengalami sakit perut setelah memakan jajanan dikantin sekolah. Kemudian siswa yang selalu membawa bekal dari rumah saat sekolah sebanyak $5,1 \%$, sering membawa bekal sebanyak $11,2 \%$ dan siswa yang kadang membawa bekal dari rumah sebanyak 33,7\%. Berdasarkan hasil analisis univariate tersebut dapat dikatakan bahwa perilaku siswa dalam menerapkan hidup bersih dan sehat dengan indikator membawa bekal dari rumah sudah baik dan adanya kesadaran dari orang tua siswa bahwa jajan sembarang dapat membahayakan kesehatan anak.

Menurut Dewayani (2015) kebiasaan jajan anak sekolah didominasi oleh makanan di luar rumah atau sering disebut dengan istilah pangan jajan. Data pengawasan BPOM terhadap pangan jajanan anak sekolah (PJAS) tahun 2010 mendapati 45\% PJAS tidak memenuhi syarat karena mengandung bahan kimia berbahaya seperti formalin, boraks, rhodamin, mengandung BTP (siklamat dan benzoat) melebihi batas aman, serta akibat cemaran mikrobiologi.

Dari penelitian yang dilakukan di SDN Garot kecamatan Darul Imarah oleh Safriana (2012), diketahui 147 responden sering mengkonsumsi makanan menggunakan saos merah seperti bakso, sosis, siomay, dll. Sedangkan jajanan minuman yang sering dikonsumsi yaitu teh poci sebanyak 144 responden dan es (es cincau, es coklat dII) sebanyak 121 respoden. Makanan tersebut diketahui tidak memiliki gizi yang cukup untuk memenuhi energi siswa setiap harinya. Selain itu, jajanan tersebut menggunakan bahan tambahan makanan. Penggunaan bahan tambahan makanan (food aditive) seperti penambah rasa, zat pengawet, pewarna dan pemanis pelu diwaspadai, karena pengunaan yang melebihi batas secara terus menerus dapat membahayakan kesehatan.

\section{Olah Raga dan Aktifitas Fisik yang Teratur}

Berdasarkan hasil analisis univariate terhadap PHBS dengan indikator olah raga dan aktifitas fisik yang teratur sudah baik, hal ini dapat dilihat bahwa siswa yang selalu mengikuti senam setiap satu minggu sekali sebanyak $67,3 \%$, akan tetapi karena sebagian siswa ada yang masuk sekolah siang hari jadi tidak pernah mengikuti senam setiap satu minggu sekali sebanyak $5,1 \%$ dengan alasan cuaca disiang hari sudah panas dan tidak baik untuk kesehatan siswa. Minat siswa untuk selalu mengikuti pelajaran olah raga sangat baik dengan frekuensi 81,6\%. Akan tetapi keinginan siswa untuk melakukan olah raga pagi sebelum sekolah masih kurang karena kurangnya arahan dari guru maupun orang tua untuk melaksanakan olah raga sebelum berangkat kesekolah, hal ini dapat dilihat dari hasil analisis univariate bahwa siswa yang selalu melakukan olah raga sebelum sekolah sebanyak $6,1 \%$ dan tidak pernah melakukan olah raga sebelum kesekolah sebanyak $73,5 \%$. Karena sudah terbiasa melakukan senam dan mengikuti pelajaran olah raga dengan sungguh-sungguh, siswa yang tidak pernah mengalami kantuk setelah berolah raga sebanyak $92,9 \%$. 
Penelitian terdahulu yang dilakukan oleh Frans Januar Iskandar (2013) menunjukan bahwa hasil analisis faktor olah raga pendukung perilaku hidup bersih dan sehat dilingkungan siswa SMA St. Fransiskus Asisi Bengkayang diperoleh rata-rata siswa menjawab sering sebesar $62,96 \%$ dan masuk kategori baik. Hasil tersebut diperoleh dari kebiasaan mereka dalam melakukan kegiatan olah raga setiap hari antara lain kebiasaan melakukan aktivitas fisik yang dilakukan serta olah raga rutin dan hal tersebut dilakukan dalam perilaku hidup bersih dan sehat di lingkungan SMA St. Fransiskus Asisi BengkayanG. (10)

Dari hasil penelitian dan penelitian terkait tersebut, dapat dikatan bahwa olah raga kesehatan membuat manusia menjadi sehat jasmani, rohani dan sosial yaitu sehat seutuhnya sesuai konsep sehat WHO. Menurut Cooper (1994), intensitas olah raga kesehatan yang cukup yaitu apabila denyut nadi latihan mencapai $65-80 \%$ DNM sesuai umur (denyut nadi maximal sesuai umur $=220$-umur dalam tahun). Sehat dinamis hanya dapat diperolah bila ada kemauan mendinamiskan diri sendiri khususnya melalui kegiatan olah raga (kesehatan)

\section{Membuang Sampah pada Tempatnya}

Berdasarkan hasil analisis univariate tentang PHBS dengan indikator membuang sampah pada tempatnya sudah baik karena tersedianya kotak sampah disetiap ruangan kelas. Hal ini dapat dilihat karena siswa yang selalu membuang sampah pada tempatnya sebanyak $70,4 \%$. Walaupun demikian, masih ada siswa yang selalu membuang sampah sembarangan sebanyak $20,4 \%$, sering membuang sampah sembarang sebanyak $11,2 \%$ dan kadang membuang sampah sembaragan sebanyak $54,1 \%$. Membuang sampah sembarangan masih dapat terjadi karena belum adanya kesadaran dari siswa bahwa membuang sampah sembarangan dapat menyumbat saluran air sehingga dapat menyebabkan banjir disekolah serta kurangnya pengawasan dari guru terhadap siswa pada saat membuang sampah. Siswa yang tidak pernah melihat pembakaran sampah disekolah sebanyak $74,5 \%$, karena sampah yang dikumpulkan diangkut oleh pertugas kebersihan dengan gerobak sampah ke tempat pembuangan sampah.

Sejalan dengan penelitian yang dilakukan oleh Frans Januar Iskandar (2013) yang menyatakan bahwa berdasarkan hasil analisis faktor membuang sampah pada tempatnya oleh siswa SMA St. Fransiskus Asisi Bengkayang diperoleh rata-rata siswa menjawab kadang-kadang sebesar $69,44 \%$ dan masuk dalam kategori tidak baik, hal tersebut diperoleh dari kebiasaan siswa sehari-hari pada saat membuang sampah pada tempatnya dirasa masih kurang dan hal tersebut dilakukan dalam perilaku hidup bersih dan sehat dilingkungan SMA St. Fransiskus Asisi Bengkayang.

Berdasarkan hasil penelitian dan penelitian terkait tersebut, dapat disimpulkan bahwa perilaku siswa dalam membuang sampah pada tempatnya belum bisa dikatakan baik karena masih ada siswa yang membuang sampah tidak pada tempatnya. Untuk menampung sampah yang dibuang oleh siswa perharinya, Madrasah Ibtidayah Az-Zahir Palembang menyediakan 10 buah tempat sampah. Tetapi sampah yang dibuang tidak dipisahkan sehingga berbagai sampah organik, anorganik, dan logam masih menjadi satu.

\section{SIMPULAN}

Perilaku siswa selalu cuci tangan pakai sabun sebelum makan sebesar $38,8 \%$ dan selalu mencuci tangan pakai sabun setelah $B A B$ dan BAK sebesar 25,5\%.

Perilaku siswa selalu mengkonsumsi jajanan di kantin sekolah sebanyak $67,3 \%$ dan siswa yang selalu membawa bekal dari rumah sebesar $5,1 \%$.

Perilaku siswa selalu mengikuti senam setiap satu minggu sekali sebesar $67,3 \%$.

Perilaku siswa selalu membuang sampah pada tempatnya sebesar $70,4 \%$.

\section{SARAN}

Hendaknya pihak sekolah mengadakan sosialisasi tentang PHBS disekolah agar sehingga pengetahuan, sikap dan perilaku siswa/siswi tentang PHBS lebih baik lagi.

Hendaknya pihak sekolah menyediakan sarana sanitasi yang lebih memadai agar perilaku siswa tentang PHBS lebih baik lagi

Hendaknya dengan adanya hasil penelitian ini diharapkan kepada pihak sekolah dan tenaga kesehatan untuk lebih meningkatkan lagi dalam mengadakan penyuluhan dan sosialisasi dalam masalah PHBS 


\section{DAFTAR PUSTAKA}

Ayuningtyas, V. N. 2012 Hubungan frekuensi jajan anak dengan kejadian diare akut pada anak sekolahn dasar di SD Sukatani 4 dan SD Sukatani 7 kelurahan sukatani, Depok. Skripsi: Universitas Indonesia.

Arikunto, Suharsimi. 2010. Prosedur Penelitian Suatu Pendekatan Praktik. Jakarta : Rineka Cipta.

Djarkoni, Ilham Habib. 2014. Hubungan Perilaku Cuci Tangan Pakai Sabun dengan Kejadian Diare di SD Advent Sario Kota Manado

Diana, Fivi Melva. 2013 Pelaksanaan Program Perilaku Hidup Bersih dan Sehat (PHBS) Di SD Negeri 001Tanjung Balai Karimun. Jurnal Kesehatan Masyarakat. (Online).

Iskandar, Frans Januar. 2013. Implementasi Perilaku Hidup Bersih Dan Sehat di Sma St Fransiskus Asisi Bengkayang.(Online)

Janis, Chyndhanita O. 2014. Gambaran Perilaku Hidup Bersih dan Sehat (Phbs) pada Siswa Sekolah Dasar Negeri 30 Manado. (Online)
Lestari, Titik. 2015. Kumpulan Teori Untuk kajian Pustaka Penelitian Kesehatan. Yogyakarta : Nuha Medika.

Maryunani, Anik. 2013. Perilaku Hidup Bersih dan Sehat (PHBS). Jakarta : CV. Trans Info Media

Notoadmodjo, Soekidjo. 2010. IImu Perilaku Kesehatan. Jakarta : PT Rineka Cipta.

Notoadmodjo, Soekidjo. 2012. Metodologi Penelitian Kesehatan. Jakarta : PT Rineka Cipta

Rahmawati, Eni. 2012. PHBS (Perilaku Hidup Bersih dan Sehat). Yogyakarta : Nuha Medika 